\title{
Cost Benefit Analysis of the Power Storage System Considering Outage Cost in the Deregulated Power Market
}

\author{
Hirokazu Tsuru Student Member (The University of Tokyo, tsuru@esl.k.u-tokyo.ac.jp) \\ Yasumasa Fujii Member (The University of Tokyo, fujii@esl.k.u-tokyo.ac.jp)
}

Keywords: power storage system, electricity deregulation, outage cost, stochastic dynamic programming

Modern sophisticated consumer goods and industrial production equipments require reliable electricity supplies. The introduction of on-site electric power storage systems has been attracting a lot of attentions as one of the very effective measures for secure procurement of electricity.

In this paper, the authors propose the mathematical model which derives the optimal operation strategies of an on-site power storage system through the use of stochastic dynamic programming technique. The model takes account of the variations and uncertainties of electricity market prices as well as the outage costs incurred by power grid failures. The market price fluctuation is modeled with stochastic differential equation of mean reverting type. The stochastic state transitions between normal and failed systems of the power grid are modeled with exponential density functions of which the main parameters are mean time to failure and mean repair time. The outline of the model is illustrated in Fig. 1.

The derived optimal operation of the storage system indicates that the economic value of the storage system may be increased substantially, if the avoided outage costs are explicitly taken into account. Figure 2 describes the economic value of the storage systems, when the mean time to failure is 500 hours and outage cost is $500 \mathrm{yen} / \mathrm{kWh}$. As shown in the figure, the profit of the power market dealings seems to be relatively small as compared with the benefit obtained by the avoidance of outage cost.

The sensitivity analysis on the selected model parameters was also conducted. The results indicate that the most influential parameters are the magnitude of outage cost and the mean time to failure

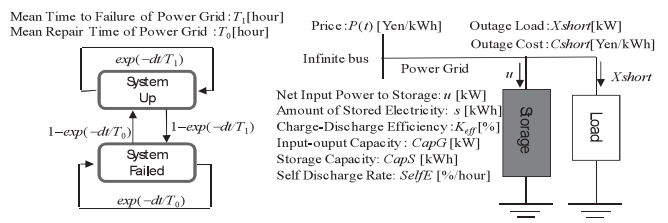

Fig. 1. Outline of the model

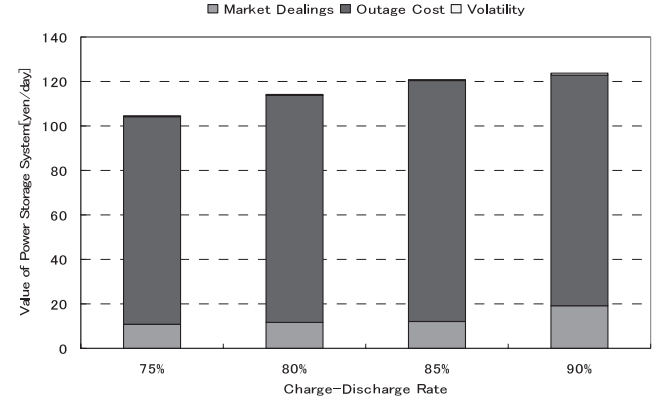

Fig. 2. Economic values of storage system

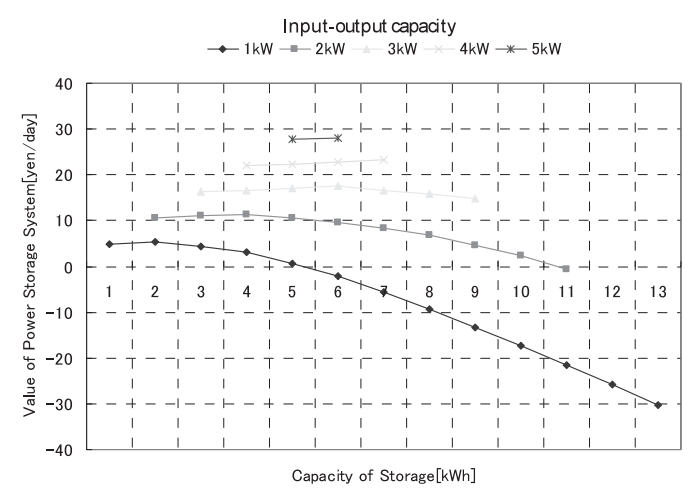

Fig. 3. Search of the optimal capacity of power storage system

of power grid.

The optimal capacity of the storage systems with limited amounts of initial investment were searched. Figure 3 indicates the economic benefits of various combinations of the storage capacities [ $\mathrm{kWh}]$ and the input-output capacities $[\mathrm{kW}]$ of the storage systems. It suggests that inadequate configuration of the system may deteriorate its economic value significantly. 


\title{
自由化環境における停電コストを考慮した 電力貯蔵設備の費用便益評価
}

\author{
学生員 都留 大和* 正 員 藤井 康正 ${ }^{* *}$

\section{Cost Benefit Analysis of the Power Storage System Considering Outage Cost in the Deregulated Power Market}

Hirokazu Tsuru*, Student Member, Yasumasa Fujii**, Member

\begin{abstract}
In this paper, the authors propose the mathematical model which derives the optimal operation strategies of an onsite power storage system through the use of stochastic dynamic programming technique. The model takes account of the variations and uncertainties of electricity market prices as well as the outage costs of power grid failures. The market price fluctuation is modeled with stochastic differential equation. The stochastic state transitions between normal and failed systems are modeled with exponential density functions. The derived optimal operation indicates that the economic value of the storage system may be increased substantially, if the avoided outage costs are explicitly taken into account. The results of the sensitivity analysis indicate that the most influential parameters are the magnitude of outage cost and the mean time to failure of power grid.
\end{abstract}

キーワード : 電力貯蔵設備, 電力自由化, 停電コスト, 確率動的計画法

Keywords: power storage system, electricity deregulation, outage cost, stochastic dynamic programming

\section{1. はじめに}

電力貯蔵とは, 夜間など需要のオフピーク時にベース電 源の電気でエネルギーを貯蔵し, 昼間のピーク負荷時にそ れを電気に变換する，いわゆる負荷の移行によって平準化 を行うものである。電力貯蔵は負荷応答性に優れているた め, 燃料費の節約や他の大型電源の熱効率向上に効果を発 揮するが，電源計画と運用において将来の不確実性に対応 しやすいという利点も有する。ライフスタイルの変化によ る負荷の先鋭化, 技術進歩による高品質電力需要の高まり への対策として，電力貯蔵設備が価值を有することは明ら かであるが, 電力自由化の下でその価值の定量的把握を目 的とした研究は少ない。自由化環境における電力貯蔵設備 を保持する電力小売事業者にとって, 電力市場価格や系統 事故などによる停電発生の不確実性は大きな経済的なりス クである。そういったリスクを考慮した上で電力貯蔵設備 の最適貯蔵戦略を導出し, 電力貯蔵設備導入による費用便

\footnotetext{
* 東京大学 大学院工学系研究科電気工学専攻

干 113-8656 東京都文京区本郷 7-3-1

School of Engineering, The University of Tokyo

7-3-1, Hongo, Bunkyo-ku, Tokyo 113-8656

** 東京大学大学院新領域創成科学研究科先端エネルギー工学専攻

干 277-8561 柏市柏の葉 5-1-5

Graduate chool of Frontier Science, The University of Tokyo

5-1-5, Kashiwanoha, Kashiwa 277-8561
}

益を定量的に分析することは, 今後の電力貯蔵設備の導入 の可能性を検討する上で重要である。

そこで著者らは, 電力市場価格の推移が確率微分方程式 で表現できるという仮定の下，解析期間内における電力市 場価格の不確実性を考慮した上での, 金融工学にも適用され る確率動的計画法による数学的モデルを提案してきた (1)(2)。 その結果, 電力貯蔵設備を用いて, 電力市場価格が安い時 間帯に電力を購入し, 電力市場価格が高い時間帯に電力を 売却することによって売買差益を得ることを目的とした場 合, たとえ売買差益の期待值が最大になるような最適貯蔵 戦略を実行したとしても，それによる費用便益を得ること は困難であるとの結論が示唆された。しかしながら前述し たように, 電力貯蔵設備の導入の目的は, 電力市場取引によ る売買差益を得ることではなく, 停電時の非常電源用, も しくは他の発電設備に対する負荷平準化効果などに主眼が 置かれているのが通常である。従って, 電力貯蔵設備の導 入は停電コストなどの軽減などに効果を発揮することが期 待され, それらを考慮することなしに電力貯蔵設備導入の 費用便益を評価することはできない。本論文では, 電力市 場価格の不確実性のみならず, 停電発生の不確実性を考慮 した数学的モデルを提案することで, 電力貯蔵設備保持者 の最適貯蔵戦略を導出するとともに, 各パラメータが電力 貯蔵設備の経済的価值に及ぼす影響について定量的に議論 し，電力貯蔵設備導入の費用便益分析を行う。 


\section{2. モデル概要}

〈2・1〉貯蔵設備保持者モデル 本論文における貯蔵 設備保持者は特定需要家と相対契約を締結し，系統事故に よる停電が発生していない正常時は卸電力取引市場を通じ て需要家に電力を調達すると同時に，保持している貯蔵設 備を用いて電力市場で電力の売買差益 (売買差損)を得る。 一方, 系統事故に伴う停電発生により電力市場から需要家 への供給が不可能となった時には, 貯蔵設備から需要家へ の電力供給を行うが，不足した供給量分にはペナルティを 支払うものとする。これを図示したのが図 1 であり，系統 の正常状態と故障状態は一定確率で遷移し, 停電発生時に は電力市場からの電力調達は不可能となるものとする。

$\langle\mathbf{2} \cdot \mathbf{2}\rangle$ 電力市場価格モデル 電力市場価格は 1 日の 中で一定のパターンを有しながら変動するといった特徴を 捉えるため, 本モデルでは電力市場価格変動について, そ れぞれの 1 日の平均変動パターンから偏差を確率変数とし て模擬する。また, 確率過程としては長期的にその平均值 に回帰する傾向があるため，ここでは以下の平均回帰モデ ルを使用することとした。

$$
d X(t)=a(t)(b(t)-X(t)) d t+\sigma(t) d Z(t)
$$

ただし, $X(t): \log \left(P(t)-A v e P(t)+e^{b(t)}\right), P(t): t$ 時点における電力市場価格 [円/kWh], Ave $P(t):$ 各 時間帯の平均価格, $a(t)$ : 回帰速度, $b(t)$ : 均衡值, $\sigma(t)$ : ボラティリティ, $d Z(t)$ : ウィナー過程

ここで, $e^{b(t)}$ は $P(t)-A v e P(t)$ が負值をとることを可能と するように導入したパラメータである。 $e^{b(t)}>A v e P(t)$ と

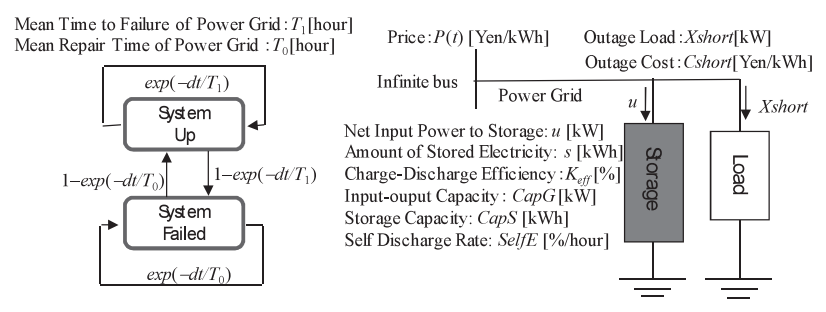

図 1 モデル概要

Fig. 1. Outline of the model.

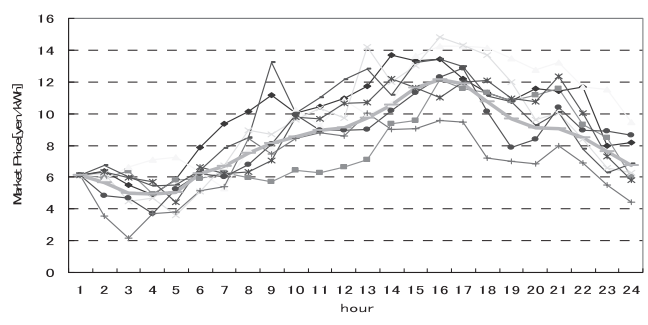

図 2 電力市場価格パスのサンプル

Fig. 2. Sample path of power market price.
なる場合は, $P(t)$ が負值をとる確率は 0 ではなくなる。し かし, そのような事態になる確率は非常に小さく, 期待值 計算への影響は誤差として無視できる。ただし，ボラティ リティの值を極端に大きくすると，この誤差は無視できな くなる。

例として, (1) 式のモデルを用いて $a=1000, b=\log 10$, $\sigma=10$ の場合の電力市場価格変動を模擬したものの結果を 図 2 に示す。なお, 今回は価格モデルとして平均回帰過程 を用いたが, ウィナー過程を含むものであれば他の過程を 用いた価格モデルを本論文の手法に適用することも可能で ある。

\section{3. 確率動的計画法を用いた総電力貯蔵コストの導出}

〈3・1〉 各時点における電力貯蔵コスト 電力貯蔵設 備の状態 $s$, その電力貯蔵設備が貯蔵している電力貯蔵 量とすると, 時点 $t$ の単位時間当たりの電力貯蔵コスト $\pi_{s, t}$ は, $F C$ を固定費, $V C_{s, t}$ を可変費として, 以下のように定 義される。

$$
\pi_{s, t}=F C+V C_{s, t}
$$

固定費 FC は, 複雑な非線形関数を用いることも可能で あるが，ここでは次のように貯蔵部と発電部の和で表わさ れるものとした。

$$
F C=P F_{s} \cdot C a p S+P F_{g} \cdot C a p G
$$

ただし, $P F_{S}$ : 貯蔵設備の貯蔵部の単位時間あたりの 固定費 [円/kWh/hour], CapS : 貯蔵部容量 [kWh], $P F_{g}$ ：貯蔵設備の発電部の単位時間あたりの固定 費 [円/kW/hour], CapG：発電部容量 $[\mathrm{kW}]$

（1）正常時の可変費正常時の可変費 $V C_{s, t}$ は, 図 1 のように, $u(s, t)$ を単位時間あたりの電力貯蔵設備内の電 力貯蔵量の変化量 $[\mathrm{kW}$ とすると,

$$
V C_{s, t}=\left\{Q_{r e}(s, u, t)+\operatorname{SelfE} \cdot s\right\} \cdot P(t) \cdot
$$

ここで, SelfE : 自己放電率 [\%/hour] であり, 市場電力 売買量 $Q_{r e}(s, u, t)$ は, 充放電効率 $K_{e f f}$ を介て次式で表わ される。

$$
\left.\begin{array}{ll}
Q_{r e}(s, u, t)=u(s, t) \cdot K_{e f f} & (\text { if } u(s, t)<0) \\
Q_{r e}(s, u, t)=u(s, t) / K_{\text {eff }} & (\text { if } u(s, t)>0)
\end{array}\right\}
$$

（2）系統故障による停電時の可変費図 1 において, 送電線事故が発生して需要家への電力供給 Xshort $[\mathrm{kW}]$ が 不可能となった場合, 停電単価を Cshort $[$ 円/kWh] として, 以下の不足電力分のペナルティ料金を可変費とする。

$$
V C_{s, t}=\text { Sshort }_{t} \cdot \max \left(\text { Xshort }_{t}+u(s, t) \cdot K_{\text {eff }}, 0\right)
$$


$\langle\mathbf{3} \cdot \mathbf{2}\rangle \quad$ 総電力貯蔵コスト

（1）偏微分方程式の導出 時点 $t$ から満期時点まで に必要となる総コストの期待值を総電力貯蔵コストとして 評価関数とする。正常状態と故障状態のそれぞれの総電力 貯蔵コスト $V_{1}, V_{0}$ と表記し, 確率変数 $X$ (電力市場価格 に対応）と電力貯蔵容量 $s$ を状態変数として考慮して, 確 率動的計画法により定式化したものが以下の (7), (8) 式で ある。

$$
\begin{aligned}
V_{1}(X, s, t)= & \min _{u}\left\{\pi_{1}(X, s, u, t) d t\right. \\
& +e^{-d t / T_{1}} E\left[V_{1}(X+d X, s+d s, t+d t)\right] \\
& \left.+\left(1-e^{-d t / T_{1}}\right) E\left[V_{0}(X+d X, s+d s, t+d t)\right]\right\}
\end{aligned}
$$

$V_{0}(X, s, t)=\min _{u}\left\{\pi_{0}(X, s, u, t) d t\right.$

$$
\begin{aligned}
& +\left(1-e^{-d t / T_{0}}\right) E\left[V_{1}(X+d X, s+d s, t+d t)\right] \\
& \left.+e^{-d t / T_{0}} E\left[V_{0}(X+d X, s+d s, t+d t)\right]\right\}
\end{aligned}
$$

たたし $E[*] ： *$ の期待值演算, $X$ : 確率変数, $T_{1}$ : 平均事故発生間隔 [hour], $T_{0}$ : 平均事故持続時間 [hour], $s$ : 電力貯蔵量 $[\mathrm{kWh}], u$ : 電力貯蔵量の 単位時間変化量 $[\mathrm{kW}], \pi_{1}(X, s, u, t)$ : 正常状態にお ける時点 $t$ での単位時間あたりの電力貯蔵コスト [円], $\pi_{0}(X, s, u, t)$ : 故障状態における時点 $t$ での単 位時間あたりの電力貯蔵コスト [円]（ペナルティ 料金支払いによる停電コストも含む)

また, 電力貯蔵量の変化は以下のように表現できる。

$$
\left.\begin{array}{l}
0 \leq s \leq \mathrm{Cap} S \\
d s(t)=u \cdot d t \cdots(|u| \leq \operatorname{Cap} G)
\end{array}\right\}
$$

ただし, Caps : 貯蔵部容量 $[\mathrm{kWh}], \operatorname{Cap} G$ : 貯蔵 効設備の実効出力の上限 (発電部容量) $[\mathrm{kW}]$

(7), (8) 式における期待值演算を伊藤の公式を用いて, 時 点 $t$ と確率変数 $X$ に関する偏微分を含む項へ变換することを 考える。まず, 時点 $t$ における電力貯蔵コスト $V(X, s, t)$ と, 時点 $t+d t$ における総電力貯蔵コスト $V(X+d X, s+d s, t+d t)$ の関係式を導出する。ここで, $V(X, s, t)$ を $V_{X, s, t}$ と略記す ると, (1) 式の確率過程に対応した伊藤の公式は (10) 式の ようになる。

$$
\begin{aligned}
d V_{X, s, t}= & V_{X+d X, s, t+d t}-V_{X, s, t} \\
= & {\left[\frac{\partial V_{X, s, t}}{\partial t}+a(b-X) \frac{\partial V_{X, s, t}}{\partial X}+\frac{1}{2} \sigma^{2} \frac{\partial^{2} V_{X, s, t}}{\partial X^{2}}\right] d t } \\
& +\sigma \frac{\partial V_{X, s, t}}{\partial X} d Z \ldots \ldots \ldots \ldots \ldots \ldots \ldots \ldots \ldots
\end{aligned}
$$

前述の (7), (8) 式に, (10) 式を代入すると, 以下の (11), (12) 式が得られる。ただし， $T_{1} \gg d t$ であることから

$$
e^{-d t / T_{1}} \approx 1-d t / T_{1}
$$

と近似し $, d t^{2}=0, E[d Z]=0$ の関係を用いる。

$$
\begin{aligned}
& V_{1, X, s, t} \\
& =\min _{u}\left\{\begin{array}{l}
\pi_{1, X, s, t} \cdot d t+V_{1, X, s+d s, t}-\left(d t / T_{1}\right) \cdot V_{1, X, s+d s, t} \\
+d t\left[\begin{array}{l}
\frac{\partial V_{1, X, s+d s, t}}{\partial t}+a(b-X) \frac{\partial V_{1, X, s+d s, t}}{\partial X} \\
+\frac{1}{2} \sigma^{2} \frac{\partial^{2} V_{1, X, s+d s, t}}{\partial X^{2}}
\end{array}\right] \\
+\left(d t / T_{1}\right) \cdot V_{0, X, s+d s, t}
\end{array}\right\}
\end{aligned}
$$

$V_{0, X, s, t}$

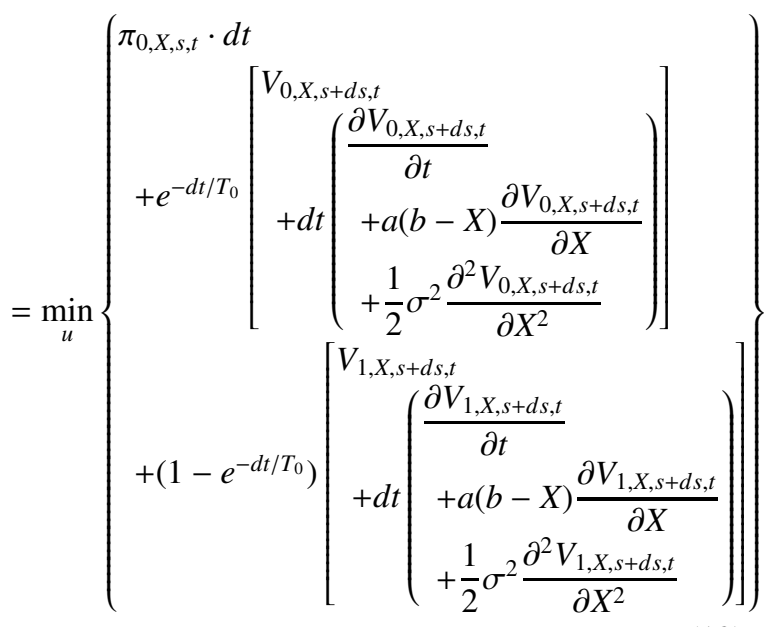

この微分方程式を差分法によって離散化し, 確率変数 $X$ (電力市場価格) の刻み番号 $m$ (刻み幅 $\Delta X, m=1,2, \ldots, M$ ) に, 時点 $t$ を時刻刻み番号 $k$ (刻み幅 $\Delta t$ ) に変更すること で，以下の差分方程式が得られる (3)(4)。

$$
V_{1, m, s, k}=\min _{u}\left\{\begin{array}{l}
\pi_{1, m, s, k} \cdot \Delta t+\left(V_{1, m, s+u \Delta t, k+1}-V_{1, m, s+u \Delta t, k}\right) \\
+V_{1, m, s+u \Delta t, k}-\left(\Delta t / T_{1}\right) \cdot V_{1, m, s+u \Delta t, k} \\
+\Delta t \cdot a\left(b-X_{m}\right) \frac{\Delta V_{1, m, s+u \Delta t, k}}{\Delta X} \\
+\frac{1}{2} \Delta t \cdot \sigma^{2} \frac{\Delta^{2} V_{1, m, s+u \Delta t, k}}{\Delta X^{2}} \\
+\left(\Delta t / T_{1}\right) \cdot V_{0, m, s+u \Delta t, k}
\end{array}\right\}
$$

$$
V_{0, m, s, k} \min _{u}\left\{\begin{array}{c}
\pi_{0, m, s, k} \cdot \Delta t+\left(1-e^{-\Delta t / T_{0}}\right) V_{1, m, s+u \Delta t, k} \\
+\left(1-e^{-\Delta t / T_{0}}\right)\left\{\begin{array}{c}
\left(V_{1, m, s+u \Delta t, k+1}-V_{1, m, s+u \Delta t, k}\right) \\
+\Delta t \cdot a\left(b-X_{m}\right) \frac{\Delta V_{1, m, s+u \Delta t, k}}{\Delta X} \\
+\frac{1}{2} \Delta t \cdot \sigma^{2} \frac{\Delta^{2} V_{1, m, s+u \Delta t, k}}{\Delta X^{2}}
\end{array}\right\} \\
+e^{-\Delta t / T_{0} t} V_{0, m, s+u \Delta t, k} \\
+e^{-\Delta t / T_{0}}\left\{\begin{array}{c}
\left(V_{0, m, s+u \Delta t, k+1}-V_{0, m, s+u \Delta t, k}\right) \\
+\Delta t \cdot a\left(b-X_{m}\right) \frac{\Delta V_{0, m, s+u \Delta t, k}}{\Delta X} \\
+\frac{1}{2} \Delta t \cdot \sigma^{2} \frac{\Delta^{2} V_{0, m, s+u \Delta t, k}}{\Delta X^{2}}
\end{array}\right\}
\end{array}\right\}
$$


ここで，右辺を最小化する $u$ を求めることが必要となる が，(13)，(14) 式の中の $k$ 時点の変数も同時決定しなくて はならない。これは計算時間上困難であるため, 右辺の $\Delta X$ の差分項を $k+1$ 時点のもので代用し，(15)，(16) 式のよう に変形し，右辺を最小化する $u$ を求める。

$$
V_{1, m, s, k}=\min _{u}\left\{\begin{array}{c}
\pi_{1, m, s, k} \cdot \Delta t+\left(V_{1, m, s+u \Delta t, k+1}-V_{1, m, s+u \Delta t, k+1}\right) \\
+V_{1, m, s+u \Delta t, k+1}-\left(\Delta t / T_{1}\right) \cdot V_{1, m, s+u \Delta t, k+1} \\
+\Delta t \cdot a\left(b-X_{m}\right) \frac{\Delta V_{1, m, s+u \Delta t, k+1}}{\Delta X} \\
+\frac{1}{2} \Delta t \cdot \sigma^{2} \frac{\Delta^{2} V_{1, m, s+u \Delta t, k+1}}{\Delta X^{2}} \\
+\left(\Delta t / T_{1}\right) \cdot V_{0, m, s+u \Delta t, k}
\end{array}\right\}
$$

$=\min _{u}\left\{\begin{array}{c}V_{0, m, s, k} \\ +\left(1-e^{-\Delta t / T_{0}}\right)\left\{\begin{array}{c}\left(V_{1, m, s+u \Delta t, k+1}-V_{1, m, s+u \Delta t, k+1}\right) \\ +\Delta t \cdot a\left(b-X_{m}\right) \frac{\Delta V_{1, m, s+u \Delta t, k+1}}{\Delta X} \\ 1 \\ +\frac{1}{2} \Delta t \cdot \sigma^{2} \frac{\Delta^{2} V_{1, m, s+u \Delta t, k+1}}{\Delta X^{2}}\end{array}\right. \\ +e^{-\Delta t / T_{0}} V_{0, m, s+u \Delta t, k+1} \\ +e^{-\Delta t / T_{0}}\left\{\begin{array}{c}\left(V_{0, m, s+u \Delta t, k+1}-V_{0, m, s+u \Delta t, k+1}\right) \\ +\Delta t \cdot a\left(b-X_{m}\right) \frac{\Delta V_{0, m, s+u \Delta t, k+1}}{\Delta X} \\ +\frac{1}{2} \Delta t \cdot \sigma^{2} \frac{\Delta^{2} V_{0, m, s+u \Delta t, k+1}}{\Delta X^{2}}\end{array}\right\}\end{array}\right\}$

(15)，(16) 式の右辺最小化により求めた $u$ を(13)，(14) 式に代入して変形すると, 以下の (17), (18) 式が得られる。

$$
\begin{aligned}
& V_{1, m, s+u \Delta t, k+1}+\pi_{1, m, s, k} \cdot \Delta t \\
& =\left(\Delta t / T_{1}\right) \cdot V_{1, m, s+u \Delta t, k}+V_{1, m, s, k} \\
& -\Delta t \cdot a\left(b-X_{m}\right) \frac{\Delta V_{1, m, s+u \Delta t, k}}{\Delta X} \\
& -\frac{1}{2} \Delta t \cdot \sigma^{2} \frac{\Delta^{2} V_{1, m, s+u \Delta t, k}}{\Delta X^{2}}-\left(\Delta t / T_{1}\right) \cdot V_{0, m, s+u \Delta t, k} \\
& \left(1-e^{-\Delta t / T_{0}}\right) V_{1, m, s+u \Delta t, k+1}+e^{-\Delta t / T_{0}} V_{0, m, s+u \Delta t, k+1} \\
& +\pi_{0, m, s, k} \cdot \Delta t \\
& =V_{0, m, s, k}-e^{-\Delta t / T_{0}}\left(a\left(b-X_{m}\right) \frac{\Delta V_{0, m, s+u \Delta t, k}}{\Delta X}\right. \\
& \left.+\frac{1}{2} \sigma^{2} \frac{\Delta^{2} V_{0, m, s+u \Delta t, k}}{\Delta X^{2}}\right) \Delta t \\
& -\left(1-e^{-\Delta t / T_{0}}\right)\left(a\left(b-X_{m}\right) \frac{\Delta V_{1, m, s+u \Delta t, k}}{\Delta X}\right. \\
& \left.+\frac{1}{2} \sigma^{2} \frac{\Delta^{2} V_{1, m, s+u \Delta t, k}}{\Delta X^{2}}\right) \Delta t
\end{aligned}
$$

電力貯蔵量 $s$ に関しても離散化 $(s=1,2, \ldots, S)$ を行い, (17), (18) 式の係数部分を係数行列として $\boldsymbol{A}_{1, k}, \boldsymbol{A}_{1, k}^{\prime}, \boldsymbol{A}_{0, k}$ などと略記すると, 以下の形式の連立方程式が得られる。

$$
\begin{gathered}
{\left[\begin{array}{c}
\boldsymbol{V}_{1, k+1}+\boldsymbol{\pi}_{1, k} \\
\left(1-e^{-\Delta t / T_{0}}\right) \boldsymbol{V}_{1, k+1}+e^{-\Delta t / T_{0}} \cdot \boldsymbol{V}_{0, k+1}+\boldsymbol{\pi}_{0, k}
\end{array}\right]} \\
\quad=\left[\begin{array}{cc}
\boldsymbol{A}_{1, k} & \left(-\Delta t / T_{1}\right) \cdot \boldsymbol{E} \\
\left(1-e^{-\Delta t / T_{0}}\right) \boldsymbol{A}_{1, k}^{\prime} & \boldsymbol{A}_{0, k}
\end{array}\right]\left[\begin{array}{l}
\boldsymbol{V}_{1, k} \\
\boldsymbol{V}_{0, k}
\end{array}\right]
\end{gathered}
$$

ただし，

$$
\boldsymbol{V}_{i, k}=\left[\begin{array}{c}
V_{i, 1, s, k} \\
\vdots \\
V_{i, m, s, k} \\
\vdots \\
V_{i, M, S, k}
\end{array}\right] \quad \boldsymbol{\pi}_{i, k}=\left[\begin{array}{c}
\pi_{i, 1, s, k} \cdot \Delta t \\
\vdots \\
\pi_{i, m, s, k} \cdot \Delta t \\
\vdots \\
\pi_{i, M, S, k} . \Delta t
\end{array}\right], \quad i=\{0,1\}
$$

（2）計算のアルゴリズム $k$ 時点の総電力貯蔵コス トベクトル $\boldsymbol{V}_{0, k}, \boldsymbol{V}_{1, k}$ と, $k+1$ 時点の $\boldsymbol{V}_{0, k+1}, \boldsymbol{V}_{1, k+1}$ の関 係が (19) 式で与えられる。次の後進的アルゴリズムを用 いて, 初期時点までの総電力貯蔵コストベクトルを求めて wく

(i) 満期時点 $(t=T)$ の境界条件として, $V_{1, m, s, T}=$ $V_{0, m, s, T}=0$ とおき, $k=T-1$ とする。

(ii) 電力貯蔵コスト $\boldsymbol{\pi}_{1, m, s, k}, \boldsymbol{\pi}_{0, m, s, k}$ を導出し, $\boldsymbol{A}_{1, k}, \boldsymbol{A}_{1, k}^{\prime}$, $\boldsymbol{A}_{0, k}$ の計算を行い, (19) 式を解いて, $V_{1, m, s, k+1}, V_{0, m, s, k+1}$ か ら $V_{1, m, s, k}, V_{0, m, s, k}$ を求める。

(iii) $k=k-1$ とし, $k=0$ となるまで (ii)を繰り返し, 初期時点までの各時点 - 各状態における総電力貯蔵コスト を導出する。

\section{4. 最適電力貯蔵戦略の導出}

〈4・1〉 ケース設定図1のモデルにおける，シミュ レーションに際してのパラメータを表 1 に示す。なお，充 放電効率とは, 貯蔵・放電それぞれに対する効率のことで あり，貯蔵・放電の一連のサイクルに対する効率はこれを 二乗することで求められる。

〈4・2〉 結 果 電力市場価格が平均值で推移した 場合の, 解析期間 3 日の場合の最適電力貯蔵戦略を次の図 3

表 1 各パラメータ

Table 1. Parameters.

\begin{tabular}{l|l}
\hline Charge-Discharge Cycle Efficiency $: K_{\text {eff }}$ & $85[\%]$ \\
\hline Storage Capacity : Cap $S$ & $4[\mathrm{kWh}]$ \\
\hline Power Capacity for Input-Output : Cap $G$ & $3[\mathrm{~kW}]$ \\
\hline Outage Cost : Cshort & $500[\mathrm{yen} / \mathrm{kWh}]$ \\
\hline Mean Time to Failure $: T_{1}$ & $500[\mathrm{hour}]$ \\
\hline Mean Repair Time : $T_{0}$ & $0.5[\mathrm{hour}]$ \\
\hline Quantity of Electricity at Outage $:$ Xshort & $5[\mathrm{~kW}]$ \\
\hline Rate of Self-Discharge $:$ SelfE & $0.7[\% / \mathrm{hour}]$ \\
\hline Equilibrium Value of Variable $X: b$ & $\log 10$ \\
\hline Speed of Regression of Variable $X: a$ & 1000 \\
\hline Volatility of Variable $X: \sigma$ & 10 \\
\hline Initial Deviation of the Market Price & 0 \\
\hline
\end{tabular}




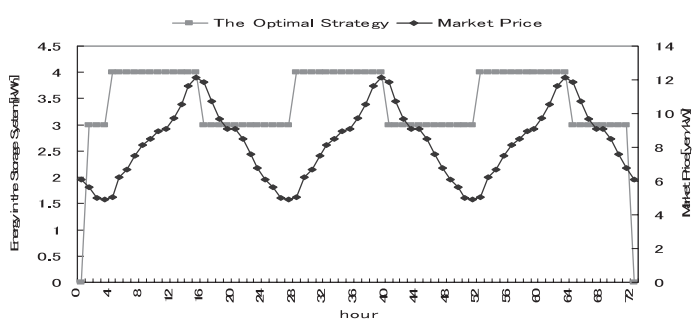

(a) Capacity of storage: $4[\mathrm{kWh}]$ capacity of; input-output: $3[\mathrm{~kW}]$

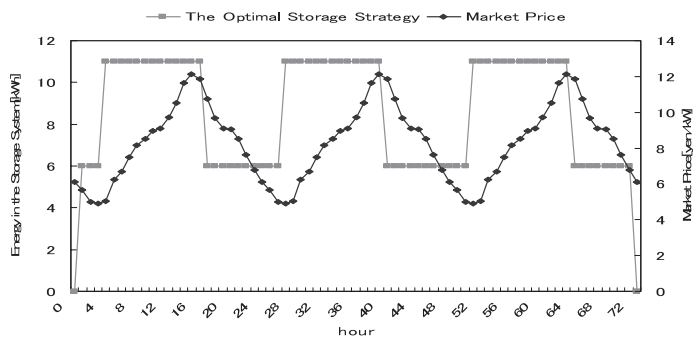

(b) Capacity of storage: $11[\mathrm{kWh}]$ capacity of; input-output: $11[\mathrm{~kW}]$

図 3 最適電力貯蔵戦略

Fig. 3. The optimal storage strategy.

に示す。解析期間を 3 日にとしたのは，3 日間連続運転す ることで，最適貯蔵戦略，費用便益が一定值に収束し，そ れ以降はほぼ同じ值をとるためである。図 3(a)の通常パラ メータにおいては, 停電対策として $3 \mathrm{kWh}$ の電力を貯蔵し つつ, 残った $1 \mathrm{kWh}$ の容量で市場売買を行い, 売買差益を得 ていることがわかる。単位時間あたりの入出力容量 $C a p G$ が $3 \mathrm{~kW}$ であるから，停電が 1 時間以上継続する状態に備 える便益よりも，市場売買で得られる便益が大きくなった ものと判断される。解析対象期間を 3 日間としたため, 最 終日には全ての電力を売りつくしている。

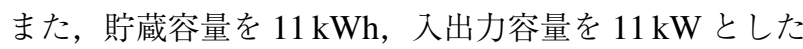
場合の最適電力貯蔵戦略を図 3(b) に示す。充放電効率が $85 \%$ あるので, $6 \mathrm{kWh}$ の貯蔵は約 $5 \mathrm{kWh}$ の供給電力量を 意味している。停電時不足電力が $5 \mathrm{~kW}$ であることから, 1 時 間程度までの停電に備えた電力貯蔵を行い, 残りの $5 \mathrm{kWh}$ 分 の貯蔵容量を市場売買に活用することが最適となっている。

今回は電力価格が平均值で推移した場合の貯蔵戦略を示 したが，もちろん他の価格带で推移した場合の最適貯蔵戦 略も導出されている。

\section{5. 電力貯蔵設備の費用便益評価}

本章では，4章で導出した最適電力貯蔵戦略を実行した 場合の電力貯蔵設備導入による経済的価值が，パラメータ によってどのように影響を受けるかについて検討し，その 費用便益評価を行う。

〈5・1〉 パラメータが貯蔵設備導入の経済的価值に及ぼ す影響貯蔵設備導入による経済的価值が，パラメータ によってどの程度影響を受けるかを検討する。簡単のため 固定費は含めていない。ここでの経済的価值とは，仮に貯 蔵設備を導入しなかった場合の解析期間内における損益の

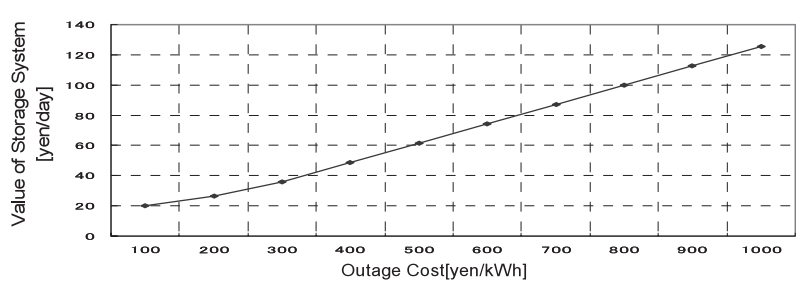

(a) Influence of outage cost

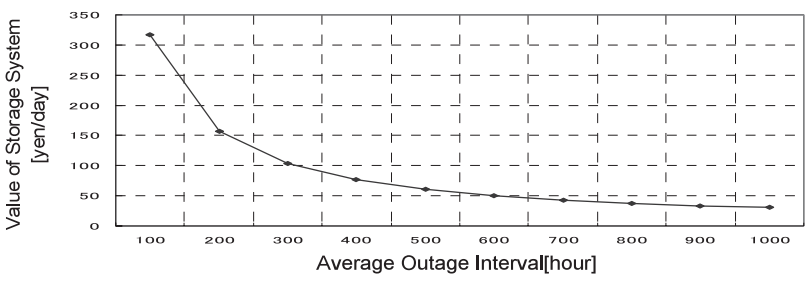

(b) Influence of average outage interval

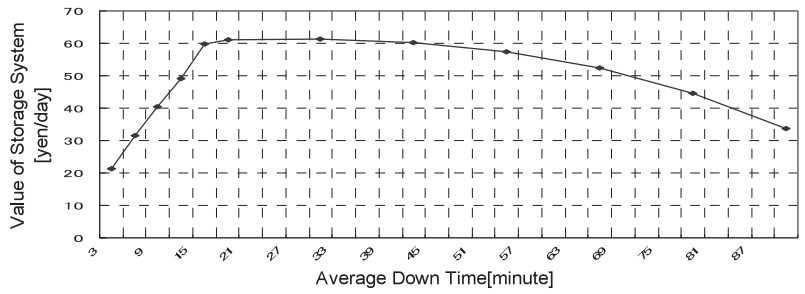

(c) Influence of average down time

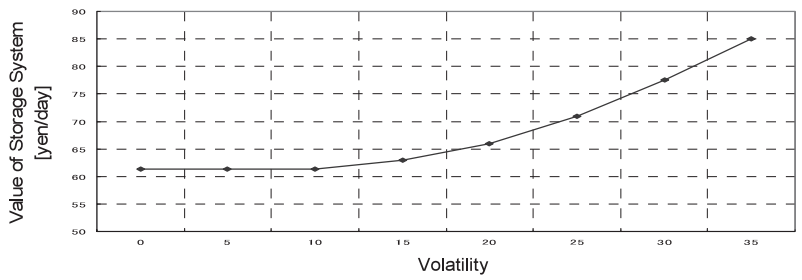

(d) Influence of volatility

図 4 パラメータと貯蔵設備の経済的価值の関係

Fig. 4. The relation of parameters and financial value of storage system.

期待值と，導入した場合の損益の期待值である総電力貯蔵 コストとの差として定義する。

（1）停電コストの影響＼cjkstart表 1 のパラメータにおいて 停電コストを変化させて, 貯蔵設備の経済的価值の感度分 析を行った結果が図 4(a) である。停電コストの増大にあわ せて貯蔵設備の経済的価值も上昇する。

（2）平均事故発生間隔の影響平均事故発生間隔と 貯蔵設備の経済的価值の関係を示したのが図 4(b) である。 発生間隔が大きくなるにつれて貯蔵設備の経済的価值は小 さくなることから, 停電が頻繁に起こる系統であればある ほど，貯蔵設備は価值を有することになる。

（3）平均事故持続時間の影響平均事故持続時間と 貯蔵設備の経済的価值を示したのが図 4(c) である。平均事 故持続時間以外は表 1 のパラメータに従っているため, 単 位時間当たりの入出力容量は $3 \mathrm{kWh}$ である。従って, あま り平均事故持続時間が長くなっても, それに対応するだけ の放電ができないため, 21 分付近で価值が飽和した後は, 
緩やかに低下している。

（4） ボラティリティの影響電力市場価格ボラティ リティの值を表 1 から任意に変化させ, 貯蔵設備の経済的 価值との関係を示したのが図 4(d) である。本論文におい ては停電対策を最優先にした貯蔵戦略が採用されやすいた め, ボラティリティが一定值を超えない限りは貯蔵戦略に 大きな影響を与えない。従って，本論文の条件であればボ ラティリティが約 15 に達しない限りは貯蔵設備の経済的 価值の上昇はないことがわかる。

（5）貯蔵設備の価值の内訳本論文における電力貯 蔵設備の経済的価值は, 停電コスト軽減による価值, 電力の 昼夜間価格差を利用した売買差益による価值，電力市場価 格のボラティリティに対する価值の 3 つの価值の合計值で あると考えられる。そこでその 3 つの価值の内訳を，表 1 のパラメータにおいて貯蔵容量を $8 \mathrm{kWh}$ に, 入出力容量を $6 \mathrm{~kW}$ に変更し，充放電効率を $75 \%$ から $90 \%$ そぞれにお いて示したものが図 5 である。価值の大部分は停電コスト 軽減による価值で占められているが，充放電効率が $90 \%$ に なると，市場売買の際の充放電ロスが小さいため，市場売 買が頻繁に行うようになる。従って, 市場売買による価值 の割合が大きくなるという結果になった。なお，ボラティ リティによる価值は，本条件下においてはほとんど生じな い。これは上述したように，ボラティリティが戦略に影響 を及ぼすには 15 を超える值をとる必要があるためである。 また，ここで想定した平均事故発生間隔 $T_{1}$ は, 停電コスト の影響が大きくなるように500 時間と比較的短く設定して

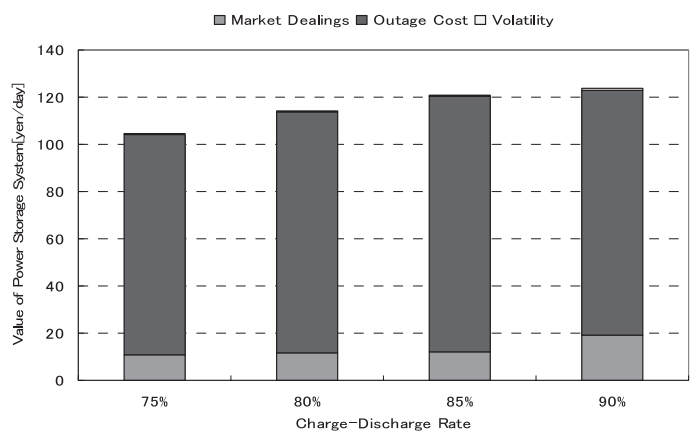

図 5 貯蔵設備の価值の内訳

Fig. 5. Breakdown of economic values of storage system.

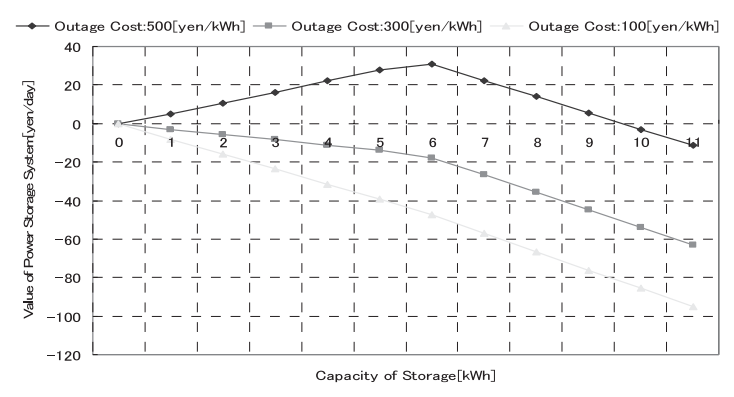

図 6 貯蔵設備の費用便益評価

Fig. 6. Cost benefit analysis of storage system.
いる。これは，必ずしも我が国の現在の系統電力のその代 表的な值ではないことには注意していただきたい。

$\langle\mathbf{5} \cdot \mathbf{2}\rangle$ 電力貯蔵設備の費用便益評価 固定費を考慮 することで貯蔵設備の費用便益を示したものが図6である。 横軸は貯蔵容量であり，ここでは単位時間当たりの入出力 容量は $100 \%$ に変更してある。なお, 建設単価としては, 二 次電池, 超電導マグネット貯蔵の技術進歩を見込んだ商用 時のコストとして予想されている值 ${ }^{(5)}$ を参考に, 発電部 4 万円 $/ \mathrm{kW}$, 貯蔵部 2 万円 $/ \mathrm{kWh}$ をそれぞれ想定し, 耐用年数 は 15 年と仮定した。停電コストが 500 円/kWh の場合は貯 蔵容量 $9 \mathrm{~kW}$ までは利益が得られるが，300 円/kWh，100 円/kWh となると貯蔵容量の值をいかなる值にしても利益 は得られないことがわかる。

また，ここでは充放電効率は $85 \%$ としているが，このと き，停電に備えて保持しておきたい電力は図 3(b) からも $6 \mathrm{kWh}$ であった（もちろん電力市場価格が高騰した場合は， たとえ貯蔵量が $6 \mathrm{kWh}$ に満たない場合であっても放電する のが最適戦略である)。従って貯蔵容量が $6 \mathrm{kWh}$ を超える と停電コスト軽減による価值の上積みがなくなってしまう ため，費用便益は減少傾向にある。

\section{6. 最適電力貯蔵設備容量の探索}

提案手法を用いれば，与えられた初期投資額において最 適電力貯蔵設備容量の探索も可能である。ここでは, 初期 投資額の上限を 30 万円とし, 固定費は $\langle 5 \cdot 2\rangle$ 節の值, そ の他のパラメータは表 1 に従うものとして探索する。結果 が図 7 であるが, 横軸に貯蔵部, 系列として発電部を表示 している。ここで想定したパラメータの場合, 停電に備え た最適貯蔵量は $6 \mathrm{kWh}$ であったため, $5 \mathrm{~kW}$ までは発電部 の值が大きくなればそれだけ, 停電コストを抑制でき, 費 用便益も大きくなる。しかし一方, 発電部が同じ容量であ れば，貯蔵部を大きくすれば費用便益も大きくなる訳では ないことがわかる。今回は設備費として発電部と貯蔵部の 和という最も単純なものを想定したが, より複雑な固定コ スト関数においての最適電力貯蔵設備容量の探索も可能で ある。

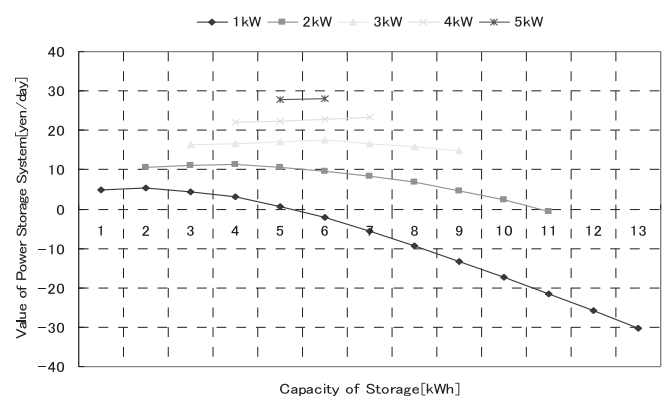

図 7 最適電力貯蔵設備容量の探索

Fig. 7. Search of the optimal capacity of power storage system. 


\section{7. まとめ}

単位時間における不確実状況下における確率動的計画法 を用いた電力貯蔵設備を保持する電力小売事業者の最適電 力貯蔵戦略及び電力貯蔵設備導入の定量的な費用便益評価 について，差分法による数值解析法を提案した。そして設 定条件に基づいて解析を行い，それらの戦略，経済的価值 に対して様々なパラメータが及ぼす影響について見当を行 い，与えられたパラメータにおける最適電力貯蔵設備容量 探索が可能であることを示した。

今後の課題として，シミュレーションに際しての時間刻 みの細分化や，発電設備と貯蔵設備両方を有する小売事業 者の貯蔵戦略の導出などが挙げられる。

(平成 19 年 2 月 23 日受付, 平成 19 年 7 月 25 日再受付)

\section{文献}

(1) Y. Saisho, T. Hayashi, Y. Fujii, and K. Yamaji: "Evaluation of Electric Power Procurement Strategies by Stochastic Dynamic Programming", IEEJ Trans. $P E$, Vol.125-B, No.3, pp.259-267 (2005-3) (in Japanese) 最所祐一・林 武人・藤井康正・山地憲治：「確率動的計画法に基つ く電力調達戦略の評価」, 電学論 B, 125, 3 pp.259-267 (2005-3)

（2）丹羽弘善 ·林 武人・藤井康正・山地憲治：「確率動的計画法を用 いた電力貯蔵システム運用計画の評価」, エネルギー・資源学会第 24 回エネルギー・資源学会研究発表会, 15-3, pp.221-224, 東京 (2005)
（3） 森平爽一郎・小島 裕：コンピュテーショナルファイナンス, 朝倉 書店 (1997)

４）沢木勝茂：ファイナンスの数理, 朝倉書店 (1997)

（5）内山洋司：「電力貯蔵技術の役割と展望」, エネルギー・資源, Vol.25, No.6, p.382 (2004)

都 留 大 和 (学生員) 1982 年 9 月生。 2005 年 3 月東京大学

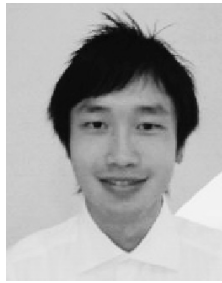
工学部電気工学科卒業。同年 4 月東京大学大学院 工学系研究科電気工学専攻入学。確率動的計画の 応用に関する研究に従事。

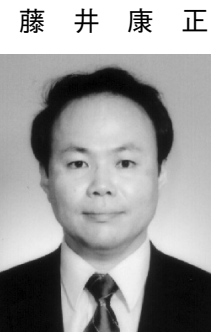

（正員） 1965 年 4 月生。 1988 年 3 月東京大学工 学部電気工学科卒業。1993 年 3 月東京大学大学 院工学系研究科電気工学専攻博士課程修了。同年 4 月横浜国立大学電子情報工学科助手。その後, 講師, 助教授を経て, 現在, 東京大学准教授 (先 端エネルギー工学専攻)。エネルギーシステムを 対象とした研究に従事。工学博士。エネルギー。 資源学会, 計測自動制御学会会員。 